Zagłada Żydów. Studia i Materiały, R. 2021, nr 17

ISSN (print): 1895-247X; eISSN: 2657-3571

DOI: https://doi.org/10.32927/zzsim.915

\title{
Joanna Ostrowska
}

https://orcid.org/0000-0001-5663-3446

\section{Karolina Sulej, Rzeczy osobiste. Opowieść o ubraniach w obozach kon- centracyjnych i zagłady, Warszawa: Wydawnictwo „Czerwone i Czarne”, 2020, $456 \mathrm{~s}$.}

Przypomniało mi się właśnie, że mam, i [...] wyciągnęłam z samego spodu walizki, spod rzeczy nienoszonych i przesypanych naftaliną, niewielki woreczek ściągnięty za pomocą wewleczonego w obrębek szpagatu, woreczek, w którym zachowało się całe nasze dawne gospodarstwo: łyżki, szczotka do zębów, trójkątny nóż skradziony z kuśnierni i strzęp ręcznika ${ }^{1}$.

Ten woreczek to bojtel - jedna z najważniejszych rzeczy osobistych więźnia i więźniarki obozów koncentracyjnych - praktycznie zapomniana przez współczesnych. Ocalała z obozu Ravensbrück Zofia Romanowiczowa kontynuuje:

całe lata miałyśmy je [rzeczy z bojtla - J.0.], a właściwie posiadałyśmy, bo mieć to za małe słowo, posiadanie lepiej określa ten uroczysty stan wiecznie czujnej, bo wiecznie zagrożonej własności, nieproporcjonalny do przedmiotu dzisiaj, ale bynajmniej nie przesadny wtedy [...]. Faktem jest, że takie, jakie były [łyżki - J.0.], liche i blaszane, stanowiły skarb do tego stopnia łakomy, że trzonki ich przedziurawiłyśmy kiedyś gwoździami na wylot, aby w ten sposób móc je nosić zawieszone na szyi, stale mieć przy sobie ${ }^{2}$.

W książce autorstwa Karoliny Sulej Rzeczy osobiste. Opowieść o ubraniach $w$ obozach koncentracyjnych i zagłady wspomniana „wiecznie zagrożona własność" staje się głównym bohaterem narracji. Po prawie osiemdziesięciu latach od zakończenia drugiej wojny światowej Sulej próbuje opowiedzieć historię więźniów i więźniarek poprzez różnorodne przedmioty codziennego użytku, które towarzyszyły im w kacetach. W jej narracji wyraźnie przeważają głosy kobiet. Już w tym miejscu warto wspomnieć, że ta książka to podsumowanie wieloletnich działań autorki, która próbuje na różne sposoby rozszczelnić historyczną narrację wojenną w kontekście historii ubioru i szerzej - historii codzienności ${ }^{3}$.

\footnotetext{
${ }^{1}$ Zofia Romanowiczowa, Przejście przez Morze Czerwone, Warszawa: PIW, 1961, s. 61-62.

${ }^{2}$ Ibidem, s. 62-63.

${ }^{3}$ W 2010 r. Karolina Sulej obroniła pracę magisterską w Instytucie Kultury Polskiej UW pt. „Moda w getcie warszawskim - praktyka i metafora” (promotorka: dr Iwona Kurz). W tomie
} 
Punktem wyjścia dla rozważań Sulej stał się strój więźniarski - symboliczny biało-niebieski pasiak, który zdominował powojenny obraz obozu koncentracyjnego, pozbawiając go cech indywidualności (s. 423) poszukiwanej przez współczesnych wyłącznie na kartach świadectw ocalałych. Odzież więźniów, niezliczone przedmioty, z którymi przybyli do obozu, oraz te, których używali w kacetach, potraktowano po wojnie jako część specyficznej scenografii muzealnej. Miały stanowić jedynie tło „poważnej opowieści” o bohaterstwie, cierpieniu, często również - szczególnie w przypadku polskich więźniów - patriotyzmie.

$\mathrm{Z}$ drugiej strony używano ich jako dowodów zbrodni, ale raczej poprzez pokazanie ich masy. Do dzisiaj w Państwowym Muzeum Auschwitz-Birkaneu na wystawie głównej w dawnym obozie macierzystym można zobaczyć góry okularów, protez, walizek, butów i innych artefaktów, które mają za zadanie skonfrontować odwiedzającego z tematem masowości prześladowań i Zagłady ${ }^{4}$. Właściciele tych przedmiotów pozostają anonimowi. Karoliny Sulej słusznie zwraca uwagę, że rzeczy osobiste wymazywano sukcesywnie już po wojnie: „Jako pamiętający, nie wykonaliśmy pracy obserwatora, na konkrecie, blisko rzeczy, blisko zapisu doświadczenia. Od razu przenieśliśmy się na poziom skrótu, ikony. W naszej narracji o drugiej wojnie światowej zanikła faktyczna opowieść ludzi i rzeczy. [...] Z naszej winy straciliśmy już bezpowrotnie wiele detali i historii. Wciąż brakuje ich w oficjalnych narracjach, spychane są do kategorii wstydu, frywolności" (s. 424).

Przez lata badania związane z rzeczami osobistymi traktowano jako temat niepoważny, zresztą całkowicie wbrew samym świadkom i świadkiniom, dla których „zagrożona obozowa własność” stanowiła specyficzną pamiątkę; uruchamiała wspomnienia i bardzo często była jedynym łącznikiem z przeszłością. W związku z tym w Rzeczach osobistych podstawowym materiałem badawczym stały się świadectwa więźniów i więźniarek - zarówno dokumenty osobiste spisane tuż po wojnie albo w latach późniejszych, często w formie literackiej, jak i relacje zbierane przez Miejsca Pamięci w Niemczech i w Polsce w różnych okresach. Jednocześnie autorka przeprowadziła wiele wywiadów $\mathrm{z}$ ocalałymi oraz - co niezwykle cenne - z badaczami obozowych artefaktów. Bohaterowie jej rozmów to nie tylko profesjonaliści - historycy, archiwiści, konserwatorzy, lecz także kolekcjonerzy-amatorzy, którzy starają się ocalić od zapomnienia dawne przedmioty obozowe, często działając całkowicie obok instytucji zajmujących się pamięcią Zagłady.

zbiorowym Ślady Holokaustu w imaginarium kultury polskiej opublikowała dwa teksty: Włos i Zwierzę (współautor: Paweł Dobrosielski).

Por. Ślady Holokaustu w imaginarium kultury polskiej, red. Justyna Kowalska-Leder, Paweł Dobrosielski, Iwona Kurz, Małgorzata Szpakowska, Warszawa: Wydawnictwo Krytyki Politycznej, 2017, s. 443-468, 505-530.

${ }^{4}$ Wystawa główna w blokach 4, 5, 6, 7, 11 powstała w $1955 \mathrm{r}$. i od tamtego czasu wprowadzono w niej tylko kilka zmian. Por. Wystawa główna - teren byłego obozu Auschwitz I, http:// www.auschwitz.org/zwiedzanie/wystawa-glowna/ (dostęp 1 VI 2021 r.). 
Rzeczy osobiste są reportażem historycznym, który nie rości sobie prawa do bycia publikacją naukową, ale powstał na bardzo solidnej bazie źródłowej. Metoda pracy autorki to zestawianie różnych materiałów historycznych i współczesnych, które tworzą wspólną narrację. Wielogłos ocalałych zbudowany na podstawie świadectw został połączony z głosem współczesnym. Sulej bowiem interesuje nie tylko przywoływanie dotychczas przemilczanych relacji byłych więźniów i więźniarek, czy też próba odczytania popularnych świadectw obozowych w zupełnie nowy sposób. Przede wszystkim jej praca podaje w wątpliwość dominujący obraz kacetów w każdym możliwym aspekcie związanym z artefaktami. Dlatego w jej książce badania odzieży obozowej autorstwa Bärbel Schmidt, która ponad dwie dekady temu jako pierwsza skatalogowała wszystkie obozowe pasiaki znajdujące się w polskich i niemieckich muzeach ${ }^{5}$ (s. 55), sąsiadują ze studium obozowej mody Marii Jezierskiej napisanym na konkurs wspomnień ogłoszony przez Muzeum w Oświęcimiu w latach sześćdziesiątych XX w. (s. 48). Cytat z wywiadu z Marią Kowalską, byłą więźniarką obozu Stutthof, która do dzisiaj przechowuje czarno-czerwony sweterek obozowy noszony także po wojnie, oznaczony karteczką z napisem „Pamiątka ze Stutthofu” (s. 381), stanowi zapowiedź opisu konserwacji tkanin i innych artefaktów z dawnych kacetów, przedmiotów nierzadko noszących ślady przemocy. Są to tak zwane tkaniny martyrologiczne, o których konserwatorka Mariola Ratajczak mówi: „Najważniejsze, żeby ubrań obozowych nie zagłuszyć [...]. Konserwator dzieł sztuki z reguły robi wszystko, żeby przywrócić zabytkom dawną świetność. W przypadku tkanin martyrologicznych jest inaczej. Konserwator musi zrobić wszystko, żeby zatrzymać w nich świadectwo" (s. 384-385).

Historia rzeczy codziennego użytku należących do więźniów i więźniarek w książce Karoliny Sulej została podzielona na kilka etapów uwzględniających zarówno biografię obozową bohaterów-właścicieli, jak i czas po wyzwoleniu. Praca składa się z jedenastu rozdziałów/esejów i posłowia rozpoczynających się od opisu procedury przyjęcia do obozu tak zwanych Zugangów, „debiutantów" mającej na celu stworzenie homogenicznej masy więźniarskiej, co oczywiście nie miało szansy powodzenia. Jak pisała Maria Jezierska, „Rygory pruskiego koszarowego drylu przewidziano szczegółowo i z dokładnością według obmyślających - absolutną. Życie nie znosi jednak sztywnych, nieelastycznych ram i w zetknięciu z życiem szablon musiał ustąpić wymogom życia. I modzie" (s. 61). Sulej punkt po punkcie opisuje, co czuły więźniarki, kiedy pozbawiano je włosów i w jaki sposób wykorzystywano ich nagość. Próbuje prześledzić historię poszczególnych strojów obozowych, ale jednocześnie pisze o czystości w obozie, także w sensie symbolicznym. W jej narracji nie brakuje tematów dotychczas tabuizowanych; pojawia się bielizna obozowa, drogocenne sznureczki

${ }^{5}$ Bärbl Schmidt, „Geschichte und Symbolik der gestreiften KZ-Häftlingskleidung“, praca doktorska, Universität Oldenburg 2000, http://oops.uni-oldenburg.de/407/1/440.pdf (dostęp 1 VI 2021 r.). 
i tasiemki, które pomagały codziennie przetrwać. Jednym z najciekawszych fragmentów w Rzeczach osobistych jest opis wielofunkcyjności przeróżnych przedmiotów „organizowanych” przez więźniarki: „Papierem można było owinąć się wokół brzucha, szmatami podszyć od spodu sukienkę. Koc chować pod ubraniem na plecach, a dodatkową podszewkę pod jakę uszyć z grubego bibulastego papieru. [...] Spadające drewniaki można było przyczepić do stopy systemem sznurków i sznurowadeł. W duże buty włożyć papiery i trochę sieczki z siennika" (s. 154).

Autorka Rzeczy osobistych porusza również temat nadzorczyń SS i ich ubioru, ze szczególnym uwzględnieniem munduru. Zahacza o tematykę fetyszu, nawiązując zarówno do fascynacji faszyzmem, jak i do współczesnych przedstawień religijnych (katolickich), w których pasiak pewnego świętego stał się wręcz ikoną popkulturową. Byłym więźniarkom towarzyszy nie tylko w wyzwolonych kacetach i obozach dla dipisów, lecz także wiele lat po wojnie. Świadkinie, z którymi Sulej rozmawia, opowiadają jej tak samo chętnie o zachowanych artefaktach z okresu wojny, jak i o swojej biografii obozowej. W końcu historia rzeczy osobistych w ujęciu tej autorki to również opowiadania o tym, co kiedyś przywłaszczono albo wyrzucono. Ostatni esej w książce koncentruje się na zbiorach symbolicznych i faktycznych współczesnych Miejsc Pamięci. Dawne więźniarskie skarby nadal można znaleźć bowiem także w domach osób zamieszkujących tereny leżące niedaleko dawnych obozów albo w lesie tuż obok Muzeum, tak jak w przypadku Stutthofu. Bardzo często kolejne pokolenia takich mimowolnych właścicieli próbują oddać „poobozowe mienie”. Historia Dagmara Kopijasza i Fundacji Pobliskie Miejsca Pamięci Auschwitz-Birkenau w Brzeszczach $^{6}$ pokazuje dobitnie, w jaki sposób i na jak masową skalę wykorzystywano po wojnie wszystko, co pozostało po więźniach i co znaleziono w samym obozie. Jednocześnie stanowi przykład poszukiwania nowych form upamiętnienia poza głównym nurtem instytucjonalnym. W tym fragmencie Rzeczy osobiste przypominają projekt fotograficzny i książkę Łukasza Baksika Macewy codziennego $u \dot{y} y t k u^{7}$, dokumentujące sposoby wykorzystania żydowskich macew w polskich miasteczkach i na wsiach po wojnie, aż do dnia dzisiejszego.

Książkę uzupełnia zbiór fotografii, które rozpoczynają poszczególne rozdziały. W przypadku takiej publikacji jest ich jednak za mało, co powoduje niedosyt. Autorka wielokrotnie wspomina o rysunkach więźniarek, powołuje się na różne obrazy (m.in. projekty mundurów, czy fragmenty wystaw), opisuje poszczególne artefakty, których niestety nie można zobaczyć. Ponadto poważnym mankamentem pracy jest brak przypisów ${ }^{8}$. I choć nie jest to publikacja naukowa, to ze względu na dużą liczbę cytacji przypisy ułatwiłyby czytelnikowi poszukiwanie

\footnotetext{
${ }^{6}$ Por. http://auschwitz-podobozy.org/ (dostęp 11 V 2021 r.).

${ }^{7}$ Łukasz Baksik, Macewy codziennego użytku, Wołowiec: Czarne, 2013.

${ }^{8} \mathrm{~W}$ książce umieszczono tylko przypisy wyjaśniające terminy w językach obcych oraz ewentualnie niektóre skróty nazw organizacji itp.
} 


\section{Recenzje}

źródeł oraz mogłyby również pełnić funkcję wyjaśnienia lub dygresji. Brakuje także aneksu z zapisem wszystkich przeprowadzonych wywiadów, które uzupełniałyby tekst główny książki, a także konkretnego wyjaśnienia, na jakiej zasadzie dobierano poszczególne świadectwa. Część z tych zarzutów jest już jednak nieaktualna, ponieważ Rzeczy osobiste to de facto pierwsza część większego projektu autorki. Nowa publikacja ukaże się już we wrześniu 2021 r. i na pewno zostanie uzupełniona o wspomniane wyżej materiały oraz rozszerzona pod względem tematycznym 9 .

Książka reporterska Karoliny Sulej wpisuje się w nurt odzyskiwania historii świadków i świadkiń poprzez ich przedmioty osobiste. Jest to publikacja wyjątkowa, ponieważ została praktycznie w całości poświęcona artefaktom należącym do byłych więźniów i więźniarek obozów koncentracyjnych i zagłady. Napisana niezwykle przystępnym językiem została już doceniona m.in. przez jury Nagrody im. Ryszarda Kapuścińskiego (nominacja). Co ciekawe, w podobnym kierunku podążają także Miejsca Pamięci i międzynarodowe archiwa. Wystarczy wspomnieć kampanię \#StolenMemory Arolsen Archives ${ }^{10}$ czy konferencję w ramach European Summer School Ravensbrück 2019, która dotyczyła kultury materialnej i kolekcjonowania przedmiotów w instytucjach zajmujących się pamięcią drugiej wojny światowej ${ }^{11}$.

Pozostaje mieć nadzieję, że publikacja Rzeczy osobistych przyczyni się również do zmian w polskich muzeach i że z czasem słowa prof. Bärbel Schmidt staną się tylko wspomnieniem dalekiej przeszłości: „We wszystkich innych dziedzinach historii Holokaustu sprawdzany jest każdy milimetr wiedzy. A z jakiegoś niewiadomego powodu w przypadku historii ubrań można pozwolić sobie na ignorancję i szybki stempel" (s. 360).

\section{BIBLIOGRAFIA}

Baksik Łukasz, Macewy codziennego użytku, Wołowiec: Czarne, 2013.

Dinge sammeln. Materielle Kulturen in KZ-Gedenkstätten [Collecting Objects. Material Cultures in Concentration Camp Memorials], Europäische Sommer-Universität Ravensbrück, 1-6 September 2019, https://www.ravensbrueck-sbg.de/fileadmin/

\footnotetext{
${ }^{9}$ Karolina Sulej, Historie osobiste. O ludziach i rzeczach w czasie wojny, Warszawa: Czerwone i Czarne, 2021.

10 „Arolsen Archives przechowuje nadal około 2500 przedmiotów należących do byłych więźniów obozów koncentracyjnych. Wszystkie te przedmioty czekają na zwrot rodzinom. Dzięki kampanii \#StolenMemory rozpoczętej w 2016 r. udało się już odnaleźć kilkaset rodzin, często z pomocą wolontariuszy prowadzących badania w różnych krajach". Por. \#StolenMemory: kampania i wystawa, https://arolsen-archives.org/pl/nauka-uczestnictwo/wystawy-i-kampanie/stolenmemory/.

${ }^{11}$ Dinge sammeln. Materielle Kulturen in KZ-Gedenkstätten [Collecting Objects. Material Cultures in Concentration Camp Memorials], Europäische Sommer-Universität Ravensbrück, 1-6 September 2019, https://www.ravensbrueck-sbg.de/fileadmin/user_upload/Gedenkstaetten/Ravensbrueck/Veranstaltungen/2019/Programm_Sommer-Uni_2019.pdf.
} 
user_upload/Gedenkstaetten/Ravensbrueck/Veranstaltungen/2019/Programm_ Sommer-Uni_2019.pdf.

Fundacja Pobliskie Miejsca Pamięci Auschwitz-Birkenau, http://auschwitz-podobozy. org/.

Romanowiczowa Zofia, Przejście przez Morze Czerwone, Warszawa: PIW, 1961.

Schmidt Bärbel, „Geschichte und Symbolik der gestreiften KZ-Häftlingskleidung“, praca doktorska, Universität Oldenburg 2000, http://oops.uni-oldenburg. de/407/1/440.pdf.

Sulej Karolina, Historie osobiste. O ludziach i rzeczach w czasie wojny, Warszawa: Czerwone i Czarne, 2021.

Sulej Karolina, „Moda w getcie warszawskim - praktyka i metafora”, 2010, praca magisterska napisana pod kierunkiem Iwony Kurz w Instytucie Kultury Polskiej Uniwersytetu Warszawskiego.

Ślady Holokaustu w imaginarium kultury polskiej, red. Justyna Kowalska-Leder, Paweł Dobrosielski, Iwona Kurz, Małgorzata Szpakowska, Warszawa: Wydawnictwo Krytyki Politycznej, 2017.

Wystawa główna - teren byłego obozu Auschwitz I, http://www.auschwitz.org/zwiedzanie/wystawa-glowna/.

\#StolenMemory: kampania i wystawa, https://arolsen-archives.org/pl/nauka-uczestnictwo/wystawy-i-kampanie/stolenmemory/. 